\title{
Nasal Ketorolac Challenge Using Acoustic Rhinometry in Patients With Aspirin-Exacerbated Respiratory Disease
}

\author{
Quiralte-Castillo J', Ávila-Castellano MR', Cimbollek S', Benaixa P², Leguisamo \\ $\mathrm{S}^{1}$, Baynova K', Labella M'1, Quiralte J'
}

\author{
'Allergy Section, Hospital Universitario Virgen del Rocío, Sevilla, Spain \\ ${ }^{2}$ Ear, Nose, and Throat Service, Hospital Universitario Virgen del Rocío, Sevilla, Spain
}

J Investig Allergol Clin Immunol 2017; Vol. 27(3): 169-174

doi: 10.18176/jiaci.0118

\begin{abstract}
Background: Safer and less time-consuming alternatives to single-blind placebo-controlled oral challenge (SBPCOC) have been sought for the diagnosis of aspirin-exacerbated respiratory disease (AERD). Nasal challenges with various nonsteroidal anti-inflammatory drugs and assessment methods have been developed.

Objective: Our objective was to evaluate the utility and safety of nasal ketorolac challenge (NKC) using acoustic rhinometry in patients with suspected AERD.

Methods: The study population comprised 36 patients with suspected AERD. NKC was performed with placebo (saline) and $13 \mathrm{mg}$ of ketorolac sprayed as aerosol into both nostrils. A positive challenge result was defined as an increase of $\geq 30 \%$ in nasal symptoms (recorded using a visual analog scale) and a 30\% drop in the sum of the volumes of both nasal cavities at 2-8 cm. Patients with a negative NKC result underwent SBPCOC with aspirin (cumulative dose of $750 \mathrm{mg}$ ).

Results: A naso-ocular reaction during NKC was detected in 21 patients. Four patients also developed mild asthma exacerbations (although only 1 experienced a decrease in $\mathrm{FEV}_{1}>15 \%$ ). No other significant adverse events occurred. The remaining 15 patients with a negative NKC result had a negative response during aspirin SBPCOC.

Conclusion: NKC assessed using acoustic rhinometry is a reliable method for the study of patients with AERD. We suggest that NKC assessed with acoustic rhinometry was useful and safe for selection of candidates for safe oral aspirin challenge.
\end{abstract}

Key words: Ketorolac. Nasal challenge. Aspirin-exacerbated respiratory disease.

\section{Resumen}

Introducción: El test de exposición simple ciego controlado con placebo (TEC) con aspirina es el patrón-oro para el diagnóstico de la enfermedad respiratoria exacerbada por aspirina (EREA), aunque presenta un riesgo elevado de reacciones durante su realización. Por este motivo, se han desarrollado diferentes procedimientos de provocación nasal con aspirina, lisina y ketorolaco.

Objetivo: Evaluar la utilidad y la seguridad del test inhalatorio nasal con ketorolaco (TNK) usando un rinómetro acústico en pacientes con sospecha de EREA.

Métodos: Se incluyeron 36 pacientes con sospecha de EREA. EI TNK se realizó con placebo (solución salina) y 13 mg de ketorolaco instilado como aerosol en ambas fosas nasales. Un test de exposición positivo se definió como un aumento del 30\% o más de los síntomas nasales registrados mediante una escala analógica visual y un descenso mayor del $30 \%$ en la suma de ambos volúmenes de las cavidades nasales entre 2 a $8 \mathrm{~cm}$ del vestíbulo nasal. Si el TNK era negativo, los pacientes se sometían a un TEC con $750 \mathrm{mg}$ de aspirina (en dosis acumulativas). Resultados: Veintiún pacientes presentaron una reacción nasoocular durante el TNK. Cuatro de ellos presentaron síntomas de asma bronquial (aunque solo uno mostró un descenso del $\mathrm{FEV}_{1}>15 \%$ ), pero no se produjeron otros acontecimientos adversos significativos. Los 15 pacientes restantes que tuvieron un TNK negativo, tuvieron una respuesta negativa durante el TEC con aspirina. Conclusión: El TNK evaluado mediante rinómetro acústico es un método fiable para el estudio de pacientes con sospecha de EREA.

Palabras clave: Ketorolaco. Provocación nasal. Enfermedad respiratoria exacerbada por aspirina. 


\section{Introduction}

A definitive diagnosis of aspirin-exacerbated respiratory disease (AERD) can only be made based on a single-blind placebo-controlled oral challenge (SBPCOC) with aspirin or another nonsteroidal anti-inflammatory drug (NSAID) carried out in patients with clinically suspected AERD [1-4]. However, SBPCOC is a time-consuming approach that can take at least 2 days to perform and result in severe reactions (mainly asthma exacerbations, laryngospasm, and even systemic symptoms in some cases). It may also require hospital admission, close monitoring, and emergency treatment to control respiratory and systemic reactions $[5,6]$. Thus, alternative methods have been developed to enhance safety and reduce the time needed for testing. Bronchial challenges [7] and nasal challenges [8-12] have been developed with various NSAIDs and assessment methods. Lee et al [8] recently presented a novel method using nasal ketorolac as the challenge drug and assessing the nasal response with a peak nasal inspiratory flow (PNIF) meter. Nasal challenge provided a rapid and safe means of confirming the diagnosis when it induced local reactions in the nasal airway of AERD patients and thus obviated the need for additional SBPCOC.

The aim of our study was to assess the diagnostic accuracy and safety of nasal ketorolac challenge (NKC) in patients with suspected AERD using acoustic rhinometry (acoR). A positive clinical response during NKC confirmed the diagnosis of AERD. A negative response, on the other hand, identified patients with suspected AERD who were candidates for increasing doses of oral aspirin until a cumulative dose of $750 \mathrm{mg}$ was reached and thus established the true negative predictive value of this procedure.

\section{Methods}

\section{Patients}

The study population comprised 36 consecutive patients with AERD, moderate-to-severe asthma, and a past history of at least 1 episode of naso-ocular reaction, asthma exacerbation, or both after intake of NSAIDs [1,3]. The data collected were as follows: age, sex, type of NSAID-induced respiratory reaction, and the NSAID involved, as well as the presence of bronchial asthma and nasal polyps (Table 1). None of the patients had episodes of urticaria and/or angioedema before controlled challenge, and $\mathrm{FEV}_{1}$ values were at least $>70 \%$ predicted, with absolute values greater than $1.5 \mathrm{~L}$. Patients with grade 3 or larger polyps were treated either medically with oral corticosteroids and fluticasone drops or surgically to reduce polyp size at least 30 days before NKC.

Drugs that could interfere with the results of NKC, such as $\mathrm{H} 1$ receptor antagonists and short-acting bronchodilator agents, were stopped 1 week and 6 hours before the procedure, respectively. However, all other asthma treatments (including montelukast, long-acting bronchodilator agents, and inhaled corticosteroids) were maintained.

Written informed consent was obtained from all patients, and the protocol was approved by the local ethics committee.
Table 1. Clinical Characteristics of AERD Patients

\begin{tabular}{|c|c|c|c|c|c|}
\hline Case & Sex & Age & $\begin{array}{l}\text { Nasal } \\
\text { Polyps }\end{array}$ & $\begin{array}{l}\text { Type of } \\
\text { NSAID } \\
\text { Reaction }\end{array}$ & $\begin{array}{l}\text { NSAID } \\
\text { Involved }\end{array}$ \\
\hline 1 & $\mathrm{M}$ & 48 & Yes & $\mathrm{BA}$ & Ibu, Met \\
\hline 2 & $\mathrm{M}$ & 67 & Yes & $\mathrm{NOR}+\mathrm{BA}$ & Ket \\
\hline 3 & $\mathrm{~F}$ & 65 & No & $\mathrm{NOR}+\mathrm{BA}$ & $\begin{array}{l}\text { ASA, Met, D, } \\
\text { Ket, Ibu }\end{array}$ \\
\hline 4 & $\mathrm{~F}$ & 67 & Yes & $\mathrm{BA}$ & ASA \\
\hline 5 & $\mathrm{M}$ & 70 & Yes & $\mathrm{NOR}+\mathrm{BA}$ & ASA \\
\hline 6 & $\mathrm{M}$ & 45 & Yes & NOR & ASA \\
\hline 7 & $\mathrm{M}$ & 28 & Yes & $\mathrm{BA}$ & ASA \\
\hline 8 & $\mathrm{~F}$ & 54 & Yes & NOR+ BA & ASA \\
\hline 9 & $\mathrm{~F}$ & 52 & Yes & $\mathrm{BA}$ & ASA, Ibu \\
\hline 10 & $\mathrm{M}$ & 56 & Yes & $\mathrm{NOR}+\mathrm{BA}$ & ASA, Met \\
\hline 11 & $\mathrm{~F}$ & 41 & Yes & $\mathrm{NOR}+\mathrm{BA}$ & ASA, Ibu \\
\hline 12 & $\mathrm{~F}$ & 68 & Yes & BA & Ibu, Met \\
\hline 13 & M & 71 & Yes & BA & Ibu \\
\hline 14 & $\mathrm{~F}$ & 59 & Yes & $\mathrm{NOR}+\mathrm{BA}$ & ASA, Met, Ibu \\
\hline 15 & $\mathrm{M}$ & 51 & Yes & NOR & ASA, Ibu \\
\hline 16 & $\mathrm{M}$ & 52 & Yes & $\mathrm{BA}$ & ASA \\
\hline 17 & M & 53 & Yes & $\mathrm{NOR}+\mathrm{BA}$ & Ibu, Met \\
\hline 18 & $\mathrm{~F}$ & 46 & Yes & $\mathrm{NOR}+\mathrm{BA}$ & ASA, Met \\
\hline 19 & $\mathrm{~F}$ & 37 & Yes & $\mathrm{NOR}+\mathrm{BA}$ & ASA, Met \\
\hline 20 & $\mathrm{~F}$ & 37 & Yes & $\mathrm{BA}$ & ASA \\
\hline 21 & M & 51 & Yes & $\mathrm{NOR}+\mathrm{BA}$ & Ibu \\
\hline 22 & $\mathrm{~F}$ & 55 & Yes & $\mathrm{NOR}+\mathrm{BA}$ & ASA, Met, Ibu, D \\
\hline 23 & M & 17 & No & $\mathrm{BA}$ & Ibu, P \\
\hline 24 & $\mathrm{~F}$ & 58 & No & $\mathrm{NOR}+\mathrm{BA}$ & Ibu \\
\hline 25 & $\mathrm{~F}$ & 40 & Yes & $\mathrm{NOR}+\mathrm{BA}$ & ASA \\
\hline 26 & $\mathrm{~F}$ & 37 & No & NOR & $\mathrm{D}$ \\
\hline 27 & $\mathrm{~F}$ & 31 & No & BA & ASA, Ibu, P, Met \\
\hline 28 & M & 22 & Yes & $\mathrm{NOR}+\mathrm{BA}$ & ASA, Ibu \\
\hline 29 & M & 54 & No & BA & Ibu, K, D \\
\hline 30 & $\mathrm{M}$ & 36 & Yes & NOR & Ibu \\
\hline 31 & $\mathrm{~F}$ & 32 & Yes & $\mathrm{NOR}+\mathrm{BA}$ & Ket \\
\hline 32 & $\mathrm{~F}$ & 43 & No & $\mathrm{NOR}+\mathrm{BA}$ & ASA, Ibu, Ket \\
\hline 33 & $\mathrm{~F}$ & 39 & No & $\mathrm{BA}$ & Ibu, Met \\
\hline 34 & $\mathrm{~F}$ & 59 & Yes & NOR & ASA, Met, Ibu \\
\hline 35 & $\mathrm{~F}$ & 46 & Yes & $\mathrm{BA}$ & Met \\
\hline 36 & $\mathrm{~F}$ & 37 & No & $\mathrm{BA}$ & ASA \\
\hline
\end{tabular}

Abbreviations: AERD, aspirin-exacerbated respiratory disease; ASA, aspirin; BA, bronchial asthma; D, diclofenac; Ibu, ibuprofen; Ket, ketoprofen; Met, metamizole; NOR, naso-ocular reaction; NSAID, nonsteroidal anti-inflammatory drugs; $\mathrm{P}$, paracetamol. 


\section{Nasal Ketorolac Challenge}

All patients were included in a previously established $\mathrm{NKC}$ whose diagnostic safety and accuracy were assessed using acoR (A1-Compact, Optomic) $[8,13]$ at least 1 month after resolution of the NSAID-induced respiratory reaction. Each patient assessed nasal blockage, rhinorrhea, itching, and sneezing before and after nasal challenge using a $100-\mathrm{mm}$ visual analog scale (VAS) with a total range of 0 to $400 \mathrm{~mm}$. Lower respiratory function was also evaluated using a spirometer (Sibelmed). The prechallenge nasal symptoms according to the VAS are shown in Table 2.

An initial single-blind challenge with saline as placebo was performed to rule out nasal hyperreactivity. If the sum of the volumes of both nasal cavities $2-8 \mathrm{~cm}$ from the nostril $\left(\mathrm{Vol}_{2-8}\right)$ declined by $<25 \%$ after administration of saline, the patient underwent nasal challenge up to a total dose of $13 \mathrm{mg}$ of ketorolac (Laboratorios Vita), which was sprayed into both nostrils. The placebo was $0.9 \%$ fresh saline solution at room temperature. A solution of $10 \mathrm{mg} / \mathrm{mL}$ of ketorolac was prepared at the beginning of the procedure by dissolving the content of 1 ampoule (volume, $1 \mathrm{~mL}$ ) of $30 \mathrm{mg}$ of ketorolac in $2 \mathrm{~mL}$ saline. One spray nebulized approximately $0.1 \mathrm{~mL}$, which is equivalent to $1 \mathrm{mg}$ of ketorolac.

The single-blind challenge was started with saline solution by spraying 2 puffs into each nostril. A graduated challenge with ketorolac solution was then performed using an initial dose of $1 \mathrm{mg}$ ( 1 puff). If no clinical response occurred and if $\mathrm{Vol}_{2-8}$ declined by $<30 \%$, incremental doses of ketorolac were administered every 30 minutes and monitored using acoR and spirometry before each dose, as follows: $2 \mathrm{mg}$ (1 spray in each nostril), $4 \mathrm{mg}$ ( 2 sprays in each nostril), and $6 \mathrm{mg}$ ( 3 sprays in each nostril). Thus, the maximum cumulative dose in the NKC was $13 \mathrm{mg}$ of ketorolac. If the patient showed any symptoms or signs during incremental exposure to ketorolac, the challenge was interrupted and the reaction treated.

A positive nasal challenge was defined as an increase of $\geq 30 \%$ in total nasal symptoms recorded by VAS and as a $\geq 30 \%$ decline in the nasal airway volume $\left(\mathrm{Vol}_{2-8}\right)$ compared with that obtained after instillation of saline solution. Lower airway signs and symptoms, such as asthma exacerbation or laryngospasm, were also recorded (if any). A 15\% decline in baseline $\mathrm{FEV}_{1}$ values during NKC was considered a positive asthmatic response. Laryngospasm was defined as crowing sounds over the trachea with an flattened inspiratory loop in the flow/volume curve.

The nasal challenge response was considered negative when no symptoms or a decrease of $<30 \%$ in $\mathrm{Vol}_{2-8}$ was observed or when no change in nasal volume or an increase of $<30 \%$ measured by VAS was recorded during the 3-hour period following instillation of the last dose of ketorolac.

\section{Oral Aspirin Challenge}

All patients with suspected AERD and a negative NKC result were included in a previously established 3-day single-blind placebo-controlled oral aspirin challenge [6]. Oral aspirin challenge was performed at least 1 week after a negative $\mathrm{NKC}$ result was obtained in a patient with suspected AERD and after withdrawal of montelukast at
Table 2. Baseline Nasal Symptoms of Patients Recorded by Visual Analog Scale

\begin{tabular}{|c|c|c|c|c|c|}
\hline Case & $\begin{array}{c}\text { Nasal } \\
\text { Blockage }\end{array}$ & Rhinorrhea & Itching & Sneezing & $\begin{array}{c}\text { Total Nasal } \\
\text { Score }\end{array}$ \\
\hline 1 & 81 & 35 & 12 & 41 & 229 \\
\hline 2 & 65 & 52 & 11 & 27 & 155 \\
\hline 3 & 63 & 66 & 53 & 68 & 250 \\
\hline 4 & 21 & 54 & 21 & 61 & 157 \\
\hline 5 & 66 & 48 & 18 & 52 & 184 \\
\hline 6 & 32 & 71 & 0 & 41 & 144 \\
\hline 7 & 54 & 39 & 22 & 66 & 181 \\
\hline 8 & 59 & 57 & 10 & 42 & 168 \\
\hline 9 & 47 & 52 & 18 & 18 & 135 \\
\hline 10 & 83 & 70 & 0 & 31 & 184 \\
\hline 11 & 77 & 51 & 22 & 56 & 206 \\
\hline 12 & 56 & 40 & 31 & 25 & 152 \\
\hline 13 & 58 & 45 & 41 & 50 & 194 \\
\hline 14 & 80 & 0 & 20 & 0 & 100 \\
\hline 15 & 70 & 75 & 0 & 0 & 145 \\
\hline 16 & 49 & 22 & 0 & 25 & 96 \\
\hline 17 & 72 & 76 & 0 & 78 & 226 \\
\hline 18 & 68 & 68 & 12 & 40 & 188 \\
\hline 19 & 75 & 56 & 21 & 32 & 184 \\
\hline 20 & 79 & 54 & 31 & 76 & 240 \\
\hline 21 & 69 & 67 & 40 & 40 & 216 \\
\hline 22 & 88 & 75 & 61 & 62 & 286 \\
\hline 23 & 55 & 52 & 61 & 48 & 216 \\
\hline 24 & 50 & 50 & 38 & 36 & 174 \\
\hline 25 & 72 & 67 & 0 & 21 & 160 \\
\hline 26 & 49 & 51 & 0 & 38 & 138 \\
\hline 27 & 61 & 60 & 12 & 22 & 155 \\
\hline 28 & 85 & 70 & 67 & 80 & 302 \\
\hline 29 & 44 & 31 & 28 & 20 & 123 \\
\hline 30 & 85 & 36 & 0 & 36 & 157 \\
\hline 31 & 81 & 67 & 21 & 44 & 213 \\
\hline 32 & 69 & 56 & 10 & 21 & 156 \\
\hline 33 & 56 & 39 & 0 & 31 & 126 \\
\hline 34 & 65 & 58 & 0 & 33 & 156 \\
\hline 35 & 51 & 60 & 0 & 12 & 123 \\
\hline 36 & 21 & 30 & 0 & 0 & 51 \\
\hline
\end{tabular}

least 5 days before in order to avoid the possibility of silent desensitization [14]. On the first day of placebo challenge, airway stability was monitored based on lung function, which was measured after each observation period (variability in $\mathrm{FEV}_{1}<10 \%$ from baseline). The first 2 aspirin doses (50 and 
$100 \mathrm{mg}$ ) were administered on day 2 , and the remaining doses (250 and $500 \mathrm{mg}$ ) were administered on day 3. Placebo and aspirin were administered in an opaque gelatin capsule at a 180-minute interval from each dose.

Table 3. Results of Nasal Ketorolac Challenge in Patients With AspirinExacerbated Respiratory Disease

\begin{tabular}{|c|c|c|c|c|c|}
\hline Case & $\begin{array}{c}\text { Cumulative } \\
\text { Provoking } \\
\text { Dose, mg }\end{array}$ & $\begin{array}{l}\text { Time } \\
\text { Elapses, } \\
\text { min }\end{array}$ & $\begin{array}{l}\text { Decline } \\
\text { in } \\
\mathrm{Vol}_{2-8}, \% \mathrm{a}\end{array}$ & $\begin{array}{l}\text { Respiratory } \\
\text { Symptoms }\end{array}$ & Result \\
\hline 1 & 13 & 45 & 34.6 & $\mathrm{NOR}+\mathrm{BA}$ & Positive \\
\hline 2 & 13 & 180 & 16 & & Negative \\
\hline 3 & 1 & 30 & 53.7 & NOR & Positive \\
\hline 4 & 7 & 30 & 34 & NOR & Positive \\
\hline 5 & 13 & 180 & 10.2 & & Negative \\
\hline 6 & 13 & 50 & 33.8 & NOR & Positive \\
\hline 7 & 13 & 180 & 6.5 & & Negative \\
\hline 8 & 13 & 180 & 15.7 & & Negative \\
\hline 9 & 3 & 20 & 39 & NOR & Positive \\
\hline 10 & 13 & 55 & 45 & NOR & Positive \\
\hline 11 & 13 & 30 & 40.5 & NOR & Positive \\
\hline 12 & 13 & 180 & 15.4 & & Negative \\
\hline 13 & 13 & 180 & 13.7 & & Negative \\
\hline 14 & 3 & 20 & 32.8 & $\mathrm{NOR}+\mathrm{BA}$ & Positive \\
\hline 15 & 13 & 120 & 49.7 & $\mathrm{NOR}+\mathrm{BA}$ & Positive \\
\hline 16 & 13 & 55 & 31.6 & NOR & Positive \\
\hline 17 & 13 & 40 & 30.3 & NOR & Positive \\
\hline 18 & 13 & 90 & 55.4 & $\mathrm{NOR}+\mathrm{BA}$ & Positive \\
\hline 19 & 13 & 50 & 30.9 & NOR & Positive \\
\hline 20 & 1 & 30 & 36.6 & NOR & Positive \\
\hline 21 & 7 & 20 & 30.4 & NOR & Positive \\
\hline 22 & 13 & 60 & 49.9 & NOR & Positive \\
\hline 23 & 13 & 180 & 18.9 & & Negative \\
\hline 24 & 13 & 180 & 12.3 & & Negative \\
\hline 25 & 13 & 180 & 7.4 & & Negative \\
\hline 26 & 13 & 180 & 13.4 & & Negative \\
\hline 27 & 13 & 90 & 33.5 & NOR & Positive \\
\hline 28 & 3 & 30 & 30.3 & NOR & Positive \\
\hline 29 & 13 & 180 & 6.8 & & Negative \\
\hline 30 & 13 & 180 & 15.6 & & Negative \\
\hline 31 & 3 & 30 & 53.5 & NOR & Positive \\
\hline 32 & 1 & 30 & 45.4 & NOR & Positive \\
\hline 33 & 13 & 180 & 19.2 & & Negative \\
\hline 34 & 13 & 120 & 30.8 & NOR & Positive \\
\hline 35 & 13 & 180 & 12.1 & & Negative \\
\hline 36 & 13 & 180 & 1.9 & & Negative \\
\hline
\end{tabular}

Abbreviations: BA, bronchial asthma; NOR, naso-ocular reaction. ${ }^{a} \mathrm{Vol}_{2-8}$, the sum of the volumes of both nasal cavities $2-8 \mathrm{~cm}$ from the nostril.
The challenge was considered positive if it fulfilled at least 1 of the following criteria: pruritus and wheals; macular and/or papular areas at any location; edema of the skin and/or external mucosa and naso-ocular and/or lower airway signs and symptoms, including bronchospasm with a fall in $\mathrm{FEV}_{1}>15 \%$; or laryngospasm. The clinical characteristics of each SBPCOC (symptoms, dose, and time elapsed) were recorded. During the challenge procedure, patients were clinically monitored at 15 minutes, 30 minutes, and every hour after administering the NSAID or placebo, or at any time symptoms were reported by the patient.

\section{Results \\ Nasal Ketorolac Challenge}

NKCs were carried out in 36 consecutive patients with suspected AERD. The result was positive in 21, with isolated nasal and ocular symptoms (Table 3 ). Four patients also developed lower respiratory tract symptoms, including mild bronchospasm and/or chest tightening, which were treated with short-acting $\beta$-agonists and oral corticosteroids. The fall in $\mathrm{FEV}_{1}$ values during $\mathrm{NKC}$ in patients with asthma symptoms was $17.83 \%, 8.96 \%, 5.46 \%$, and $12.26 \%$ in patients $1,14,15$, and 18 , respectively. No significant changes in $\mathrm{FEV}_{1}$ values were observed in patients who experienced a naso-ocular reaction alone. Twelve patients reacted after exposure to 13 $\mathrm{mg}$ of ketorolac (57\% of cases), 3 patients reacted at $1 \mathrm{mg}$, 4 at $3 \mathrm{mg}$, and 2 at $7 \mathrm{mg}$.

A post hoc analysis was performed to compare the differences in clinical reaction in relation to the dose of ketorolac in 4 patients $(9,10,11$, and 22), who were successfully desensitized with aspirin owing to suboptimal control of nasal and sinus symptoms and anosmia and were twice challenged with nasal ketorolac during the process (Table 4). The $\mathrm{Vol}_{2-8}$ values obtained during the first clinical reaction and the challenge dose of ketorolac did not differ significantly from those observed in a subsequent challenge.

Table 4. Reproducibility of Response to Nasal Ketorolac Challenge in 4 Patients With Aspirin-Exacerbated Respiratory Disease

\begin{tabular}{lccc} 
Case & $\begin{array}{c}\text { Ketorolac } \\
\text { Provoking } \\
\text { Dose, mg }\end{array}$ & $\begin{array}{c}\text { Vol }_{2-8} \text { Decrease After Clinical Reaction } \\
\text { First NKC }\end{array}$ & $\begin{array}{c}\text { Second NKC } \\
\text { Secon }^{\mathrm{b}}\end{array}$ \\
\hline 9 & 3 & 39.0 & 31.8 \\
10 & 13 & 45.0 & 48.4 \\
11 & 13 & 40.5 & 31.6 \\
22 & 13 & 49.9 & 41.3
\end{tabular}

Abbreviation: NKC, nasal ketorolac challenge.

${ }^{\mathrm{a}} \mathrm{Vol}_{2-8}$, the sum of the volumes of both nasal cavities $2-8 \mathrm{~cm}$ from the nostril.

bMaximum decline in the nasal airway measured as Vol2-8 compared with that obtained after instillation of saline solution (\%).

'The time elapsed between the first and second nasal ketorolac challenge was at least 6 months for each patient. 
The remaining 15 patients experienced no clinical reactions during $\mathrm{NKC}$ and underwent an additional controlled oral challenge in order to confirm or rule out AERD.

\section{Oral Aspirin Challenge}

Fifteen patients with a convincing history of AERD and negative NKC results underwent SBPCOC with aspirin and tolerated a cumulative dose of $750 \mathrm{mg}$ (Table 3).

\section{Discussion}

Moderate-to-severe, unstable, and poorly controlled asthma is common in AERD patients and induces many clinicians to bypass oral challenge with NSAIDs owing to the increased risk of adverse reactions and to the fact that it is time-consuming. Therefore, challenges with NSAID are rarely performed for diagnostic purposes outside research units $[2-4,6]$.

We demonstrated that using NKC assessed with acoR was a safe, effective, and reproducible method for diagnosis of AERD. Unlike oral challenges, NKC caused fewer adverse extrapulmonary effects or bronchospasms and induced mainly isolated naso-ocular reactions. With the exception of 1 patient who developed asthma symptoms with a $>15 \%$ drop in $\mathrm{FEV}_{1}$, no other severe adverse events occurred. In addition, all of the study patients continued with their asthma treatment (including montelukast, a leukotriene modifier) during the $\mathrm{NKC}$, thus decreasing the likelihood of severe lower respiratory reactions without significantly masking naso-ocular symptoms [15]. The patients experienced the symptoms after a mean of 49 minutes, ie, between the 2 -fold and 4 -fold doses of ketorolac in $85 \%$ of cases.

We also explored the ability of NKC assessed by acoR to predict responses to the oral aspirin challenge. In the present study, we showed that a negative nasal response to $13 \mathrm{mg}$ of ketorolac (cumulative dose) is always followed by a negative response to aspirin oral challenge. This finding would allow the clinician to perform an SBPCOC with aspirin with the certainty of a safe outcome and - possibly — shorter protocols. However, in a recent study, up to $10 \%$ of patients with a negative NKC result experienced respiratory reactions during a subsequent oral aspirin challenge. The authors evaluated 100 patients with AERD (by clinical history and positive oral aspirin challenge) who were rechallenged with intranasal ketorolac [8]. A positive reaction (defined as rhinitis, conjunctivitis, and/or bronchospasm with a significant

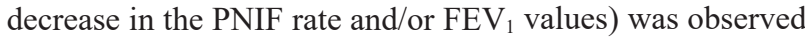
in $90 \%$. These observations were confirmed in a recent study on the feasibility of PNIF as an objective measurement in the assessment of a reaction to nasal ketorolac [9]. The fact that all of the patients in the present study tolerated aspirin challenge after a negative NKC result could be because of the use of acoR instead of a PNIF. Recently, Miller at al [10] also reported a high percentage of positive challenge results (45\%) with $325 \mathrm{mg}$ of aspirin in patients who had previously experienced a negative acoR-monitored nasal challenge with aspirin-lysine [10]. Anterior active rhinomanometry used as an objective assessment method revealed that only 16 of 20 patients with oral challenge-proven AERD (80\%) had a positive nasal response to the nasal challenge with aspirinlysine [11]. These different clinical outcomes suggest that the NSAID, the objective method used to measure the changes in nasal airways, or both might have a relevant effect on the results of nasal NSAID challenges.

In conclusion, NKC assessed by acoR was characterized by a lower incidence of adverse effects during the procedure, and, although the present sample was not large enough to fully determine the negative predictive value of acoustic rhinometry, our data seem to suggest that the combination of NKC assessed with acoR was a safe and useful procedure for selection of candidates to undergo safe oral aspirin challenge.

\section{Funding}

The authors declare that no funding has been received for the present study.

\section{Conflicts of Interest}

The authors declare that they have no conflicts of interest.

\section{Previous Presentation}

This study was awarded the Saint Luke Prize for Research Medicine 2015 from the Real e Ilustre Colegio Oficial de Médicos de la Provincia de Sevilla.

\section{References}

1. Makowska J, Lewandowska-Polak A, Kowalski ML. Hypersensitivity to Aspirin and other NSAIDs: Diagnostic Approach in Patients with Chronic Rhinosinusitis. Curr Allergy Asthma Rep. 2015;15:47.

2. Navabi M, Esmaielzadeh $H$, Arshi S, Bemanian MH, Fallahpour M, Bahrami A, Mortazavi N, Kamrava K, Farhadi M, Taghipour $\mathrm{R}$, Rezaei N. Aspirin hypersensitivity in patients with chronic rhinosinusitis and nasal polyposis: frequency and contributing factors. Am J Rhinol. 2014;28:239-43.

3. Kowalski ML, Asero R, Bavbek S, Blanca M, Blanca-Lopez N, Bochenek G, Brockow K, Campo P, Celik G, Cernadas J, Cortellini G, Gomes E, Niżankowska-Mogilnicka E, Romano A, Szczeklik A, Testi S, Torres MJ, Wöhrl S, Makowska J. Classification and practical approach to the diagnosis and management of hypersensitivity to nonsteroidal antiinflammatory drugs. Allergy. 2013;68:1219-32.

4. Simon RA, Dazy KM, Waldram JD. Aspirin-exacerbated respiratory disease: characteristics and management strategies. Expert Rev Clin Immunol. 2015;11:805-17.

5. Hope AP, Woessner KA, Simon RA, Stevenson DD. Rational approach to aspirin dosing during oral challenges and desensitization of patients with aspirin-exacerbated respiratory disease. J Allergy Clin Immunol. 2009;123:406-10.

6. Quiralte J, Blanco C, Delgado J, Ortega N, Alcntára M, Castillo R, Anguita JL, Sáenz de San Pedro B, Carrillo T. Challenge-based clinical patterns of 223 Spanish patients with nonsteroidal anti-inflammatory-drug-induced-reactions. J Investig Allergol Clin Immunol. 2007;17:182-8. 
7. Ta V, Simon R. State of the art: medical treatment of aspririn exacerbated respiratory disease (AERD). Am J Rhinol Allergy 2015;29:41-3.

8. Lee $R U$, White $A A$, Ding $D$, Dursun $A B$, Woessner $K M$, Simon RA, Stevenson DD. Use of intranasal ketorolac and modified oral aspirin challenge for desensitization of aspirinexacerbated respiratory disease. Ann Allergy Asthma Immunol. 2010;105:130-5.

9. Celikel S, Stevenson DD, Erkorkmaz U, White AA. Use of nasal inspiratory flow rates in the measurements of aspirininduced respiratory reactions. Ann Allergy Asthma Immunol. 2013;111:252-5.

10. Miller B, Mirakian R, Gane S, Larco J, Sannah AA, Darby Y, Scadding $G$. Nasal lysine aspirin challenge in the diagnosis of aspirin-exacerbated respiratory disease. Clin Exp Allergy. 2013:43:874-80.

11. Alonso-Llamazares $A$, Martinez-Cocera C, Dominquez-Ortega J, Robledo-Echarren T, Cimarra-Alvarez M, Mesa del Castillo M. Nasal provocation test (NPT) with aspirin: a sensitive and safe method to diagnose aspirin-induced asthma (AIA). Allergy. 2002;57:632-5.

12. Muñoz-Cano R, Bartra J, Sanchez-Lopez J, Picado C, Bissinger I, Valero A. Acoustic Rhinometry and Aspirin Nasal Challenge in the Diagnosis of Aspirin-Intolerant Asthma: Clinical Finding and Safety Aspects. Int Arch Allergy Immunol. 2013;160:307-12.
13. Quiralte J, Avila R, Cimbollek S. A phenotype-based classification of NSAIDs hypersensitivity: new patients, new challenges. Allergy. 2014;69:814-5.

14. White AA, Bosso JV, Stevenson DD. The clinical dilemma of silent desensitization in aspirin-exacerbated respiratory disease. Allergy Asthma Proc. 2013;34:378-82.

15. White AA, Ludington E, Mehra P, Stevenson DD, Simon RA Effect of leukotriene modifier drugs on the safety of oral aspirin challenges. Ann Allergy Asthma Immunol. 2006;97:688-93.

- Manuscript received July 27, 2016; accepted for publication October 17, 2016.

\section{Joaquin Quiralte}
Allergy Section
Hospital Universitario Virgen del Rocío
Avenida Manuel Siurot, s/n
41013 Sevilla, Spain
E-mail: joaquinquiralte@gmail.com 